\title{
Wpływ niezgodności spawalniczych na właściwości mechaniczne złączy spawanych pod wodą metodą mokrą
}

\section{Effect of welding imperfections on mechanical properties of underwater wet welded joints}

\section{Streszczenie}

Przedstawiono charakterystykę spawania pod wodą metodą mokrą elektrodami otulonymi. Na podstawie badań eksperymentalnych oceniono wpływ niezgodności spawalniczych na właściwości mechaniczne wykonanych złączy. Stwierdzono, że występujące niezgodności spawalnicze nie wpływają na szczelność wykonanych połączeń, ale pogarszają właściwości mechaniczne związane z próbą zginania.

\section{Abstract}

The paper presents the characteristics of manual metal arc underwater wet welding. On the basis of experimental studies the effect of welding defects on mechanical properties of welded joints was estimated. It was found out that occurring of welding imperfections have no influence on leak tightness of welded joints but cause the decrease of mechanical properties associated with bending test.

\section{Wstęp}

Spawanie mokre elektrodami otulonymi pod wodą to jedna z najczęściej stosowanych metod, która wykorzystywana jest $w$ remontach, regeneracji oraz naprawach elementów jednostek pływających, platform wiertniczych, elementów nabrzeży i innych konstrukcji znajdujących się pod woda (rys. 1). Cecha charakterystyczną spawania mokrego jest bezpośredni kontakt spawanych elementów, uchwytów spawalniczych, materiałów dodatkowych oraz w pewnych sytuacjach osprzętu z wodą. Łuk elektryczny jest nieosłonięty, a cały proces spawania odbywa się przy ciśnieniu panującym na danej głębokości.

Poza podstawową zaletą, jaką jest prostota tej metody, spawanie mokre ma sporo wad. Zaliczyć do nich

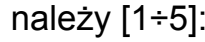

- wysoki poziom wodoru dyfundującego w stopiwie (duża ilość pary wodnej w obszarze jarzenia łuku),

Dr inż. Grzegorz Rogalski - Politechnika Gdańska.
- duże prędkości stygnięcia złączy spawanych związane z szybkim odbieraniem ciepła przez wodę (rys. 2),

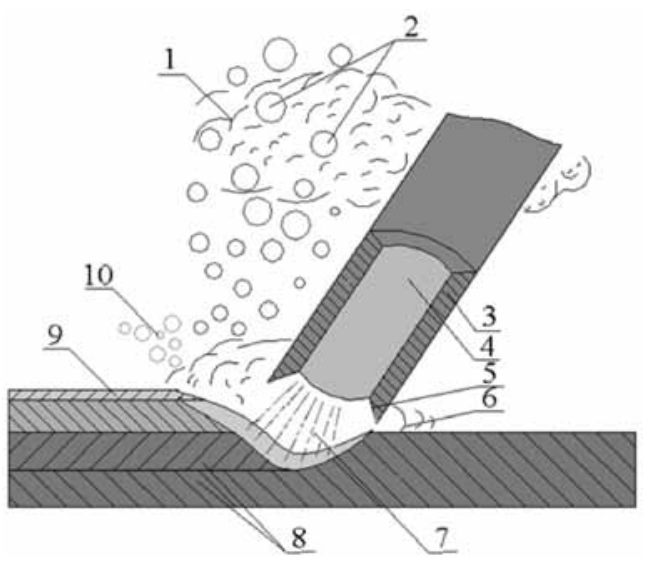

Rys. 1. Spawanie mokre elektrodą otuloną, gdzie: 1 - para wodna, 2 - pęcherze gazowe, 3 - otulina, 4 - rdzeń, 5 - stapiana otulina, 6 - jeziorko ciekłego metalu, 7 - łuk elektryczny, 8 - materiał rodzimy, 9 - żużel, 10 - gazowe produkty stapiania otuliny [2]

Fig. 1. Manual metal arc wet welding, where: 1 - steam, 2 - gas bubbles, 3 - covering of electrode, 4 - core, 5 - melted covering of electrode, 6 - weld pool, 7 - electric arc, 8 - parent material, 9 - slag, 10 - gas products [2] 


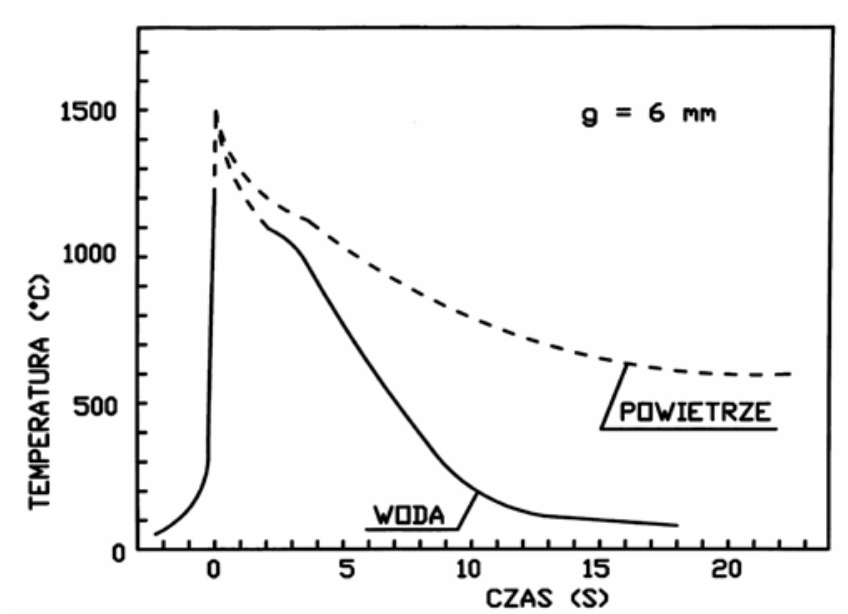

Rys. 2. Cykle cieplne spawania dla spawania pod wodą i na powietrzu elektrodą otuloną (MMA/111), dla płyty o grubości $6 \mathrm{~mm}$ [2] Fig. 2. Thermal cycles of underwater and in the air welding with the MMA method, thickness of the plate $6 \mathrm{~mm} \mathrm{[2]}$

- dużą głębokość spawania, ze wzrostem której rośnie ciśnienie, prowadzi do niekorzystnych zmian zachodzących w łuku elektrycznym oraz w jeziorku spawalniczym, przy czym dodatkowo zwiększa się liczba odprysków,

- ograniczoną widoczność w miejscu spawania wywołaną gazami oraz parami, co utrudnia pracę nurka-spawacza,

- trudną manipulacją uchwytem elektrodowym,

- ograniczenie zastosowania do głębokości ok. $50 \mathrm{~m}$,

- czasochłonne i kosztowne szkolenie nurków-spawaczy.

Złącza spawane wykonane w warunkach podwodnych muszą charakteryzować się założonym poziomem jakości. Poziom ten może być określony przez zleceniodawcę lub odpowiednie normy przedmiotowe, np. AWS D3.6M czy PN-EN ISO 5817, na które również może powoływać się zamawiający usługę. Ze względu na charakterystykę spawania mokrego uzyskanie spoin bez niezgodności spawalniczych jest trudne. Wymaga to uwzględnienia wielu czynników, np. głębokości spawania, warunków atmosferycznych, stanu powierzchni spawanych elementów, umiejętności nurka-spawacza, gatunku materiału podstawowego itp. Pomimo że umiejętności nurków-spawaczy są weryfikowane przez ich certyfikowanie zgodnie z wymaganiami EN ISO 15618-1 [6] lub AWS D3.6M, to prawdopodobieństwo występowania niezgodności spawalniczych jest stosunkowo wysokie. Najczęściej mogą pojawić się: pęknięcia zimne, pęcherze gazowe, porowatość spoin, żużle, przyklejenia międzywarstwowe, braki przetopu. Często prace spawalnicze pod wodą mają zapewnić tylko szczelność łączonych elementów, natomiast właściwości wytrzymałościowe nie są istotne. Są jednak połączenia, które muszą jednocześnie spełniać kryteria szczelności i wytrzymałości. W takim przypadku osoby wykonujące prace spawalnicze muszą być wysoko wykwalifikowane oraz mieć duże doświadczenie w zakresie wykonywanych prac, a kadra inżynierska nadzorująca te prace musi wiedzieć, $w$ jakim stopniu niezgodności spawalnicze obniżają właściwości wytrzymałościowe oraz wpływają na szczelność wykonanych połączeń.

\section{Cel pracy}

Celem pracy było określenie wpływu niezgodności spawalniczych na właściwości mechaniczne oraz szczelność złączy spawanych pod wodą metodą mokrą przy zastosowaniu spawania elektrodami otulonymi.

\section{Badania własne}

Osiągnięcie celu pracy wymagało opracowania planu badań, który obejmował:

- Założenia materiałowe (dobór gatunku stali).

- Ustalenie warunków realizacji eksperymentu.

- Ustalenie parametrów technologicznych spawania na podstawie wykonania złączy próbnych testowych.

- Wykonanie złączy próbnych przeznaczonych do dalszych badań.

- Badania wizualne (VT) wg PN-EN ISO 17637 [7].

- Próba szczelności.

- Badania radiograficzne (RT) wg PN-EN ISO 1435 [8].

- Badania makroskopowe wg PN-EN 1321 [9].

- Badania wytrzymałościowe:

- próba zginania wg PN-EN ISO 5173 [10],

- próba rozciągania wg PN-EN ISO 4136 [11].

\section{Warunki realizacji eksperymentu}

Po analizie czynników związanych z procesem spawania pod wodą oraz stosowanych materiałów podstawowych założono następujące warunki realizacji eksperymentu:

- Metoda spawania: 111.

- Materiał podstawowy: stal S355J2G3.

- Grubość elementów: a) $t=10 \mathrm{~mm}, \mathrm{~b}) \mathrm{t}=12 \mathrm{~mm}$.

- Głębokość spawania: a) $200 \mathrm{~mm}$; b) $3000 \mathrm{~mm}$.

- Rodzaj elektrody: a) EN ISO 2560: E $4221 \mathrm{Ni}$ RR 51 (elektroda do spawania pod wodą: Barracuda); b) EN ISO 2560-A: E 380 R 11 (elektroda do spawania na powietrzu: Omnia 46).

- Pozycja spawania: PA.

- Rodzaj złącza oraz spoiny: doczołowe, spoina czołowa (BW).

- Temperatura wody: $13^{\circ} \mathrm{C}$.

- Temperatura powietrza: $20^{\circ} \mathrm{C}$.

Próbki wykonano na stanowisku do spawania pod wodą na małych głębokościach (do $1 \mathrm{~m}$ ) w Zakładzie Inżynierii Spajania PG oraz w akwenie wodnym. 


\section{Charakterystyka materiału podstawowego}

W badaniach zastosowano niestopową stal konstrukcyjną S355J2G3 (Wr. Nr. 1.0570). Jest to gatunek charakteryzujący się dobrą spawalnością. Główne ryzyko podczas spawania to możliwość formowania się pęknięć zimnych, które rośnie wraz ze wzrostem grubości łączonych elementów. W tablicy I przedstawiono skład chemiczny oraz właściwości mechaniczne stali S355J2G3 użytej do badań.

\section{Ustalenie parametrów technologicznych spawania i wykonania złączy próbnych}

W kolejnym etapie wykonano próby technologiczne spawania złączy testowych z uwzględnieniem wytypowanych zmiennych istotnych. Ustalono warunki przygotowania złącza przed spawaniem oraz prądowe parametry spawania. Na podstawie zapisów z prób opracowano instrukcje technologiczne spawania WPS, które wykorzystano do spawania próbek. W tablicach II i III przedstawiono geometrię elementów przed spawaniem, kolejność spawania oraz zastosowane parametry spawania.

\section{Wyniki badań i ich analiza}

\section{Badania wizualne}

Badania wizualne przeprowadzono zgodnie z wymaganiami PN-EN ISO 17637 [7]. Badaniu poddano $100 \%$ spoiny i SWC. Badania wykonano bezpośrednio przy użyciu standardowego oprzyrządowania. $\mathrm{Na}$ ich podstawie stwierdzono występowanie niezgodności spawalniczych typu podtopienia lica, niepełne wypełnienia rowka spawalniczego, rozpryski, nawis. Na rysunkach 3 i 4 przedstawiono złącza próbne z zaznaczonymi niezgodnościami spawalniczymi.

Tablica I. Właściwości mechaniczne oraz skład chemiczny stali S355J2G3

Table I. Mechanical properties and chemical composition of S355J2G3 steel

\begin{tabular}{|c|c|c|c|c|c|c|c|c|c|c|c|c|}
\hline \multicolumn{10}{|c|}{ Zawartość składników, \% wag. } & \multicolumn{3}{|c|}{ Właściwości mechaniczne } \\
\hline $\mathrm{C}$ & $\mathrm{Si}$ & $\mathrm{Mn}$ & $\mathrm{P}$ & $\mathrm{S}$ & $\mathrm{Cr}$ & $\mathrm{Ni}$ & $\mathrm{Cu}$ & $\mathrm{Al}$ & $\mathrm{C}_{\mathrm{e}}$ & $\mathrm{R}_{\mathrm{e}}, \mathrm{MPa}$ & $\mathrm{R}_{\mathrm{m}}, \mathrm{MPa}$ & $A_{5}, \%$ \\
\hline 0,17 & 0,35 & 1,44 & 0,014 & 0,014 & 0,04 & 0,077 & 0,3 & 0,02 & 0,44 & 464 & 577 & 22,1 \\
\hline
\end{tabular}

Tablica II. Parametry spawania próbki 10/111/PA elektrodą otuloną do spawania pod wodą Barracuda (EN ISO 2560: E 42 2 1 Ni RR 51) Table II. Parameters of welding of specimen 10/111/PA with Barracuda electrode (EN ISO 2560 : E 4221 Ni RR 51)

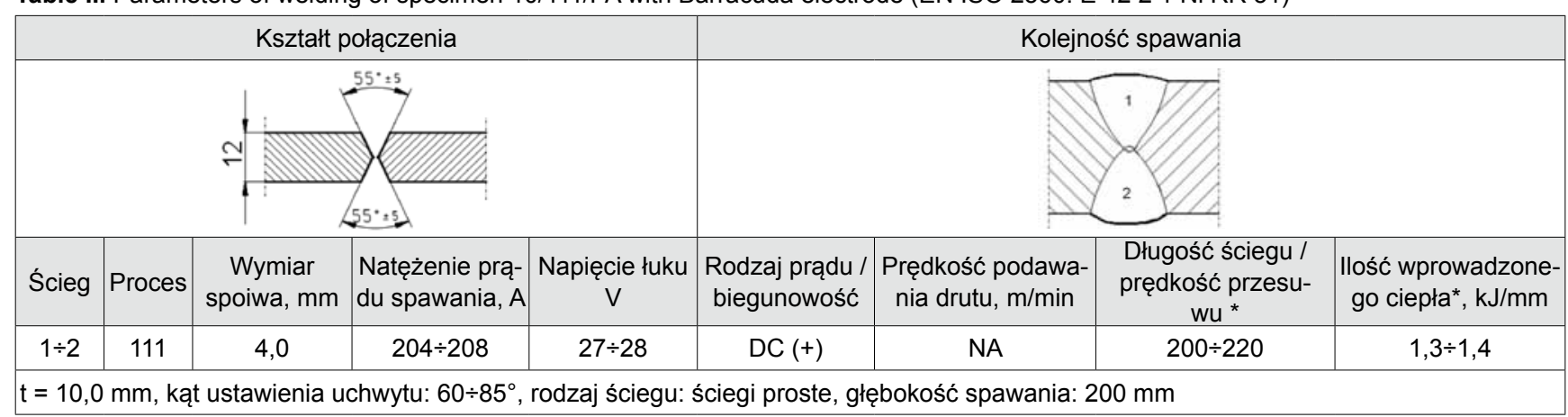

Tablica III. Parametry spawania próbki 12/111/PA elektrodą otuloną do spawania na powietrzu Omnia 46 (EN ISO 2560-A: E 38 0 R 11) Table III. Parameters of welding of specimen 12/111/PA with Omnia electrode (EN ISO 2560-A: E 380 R 11)

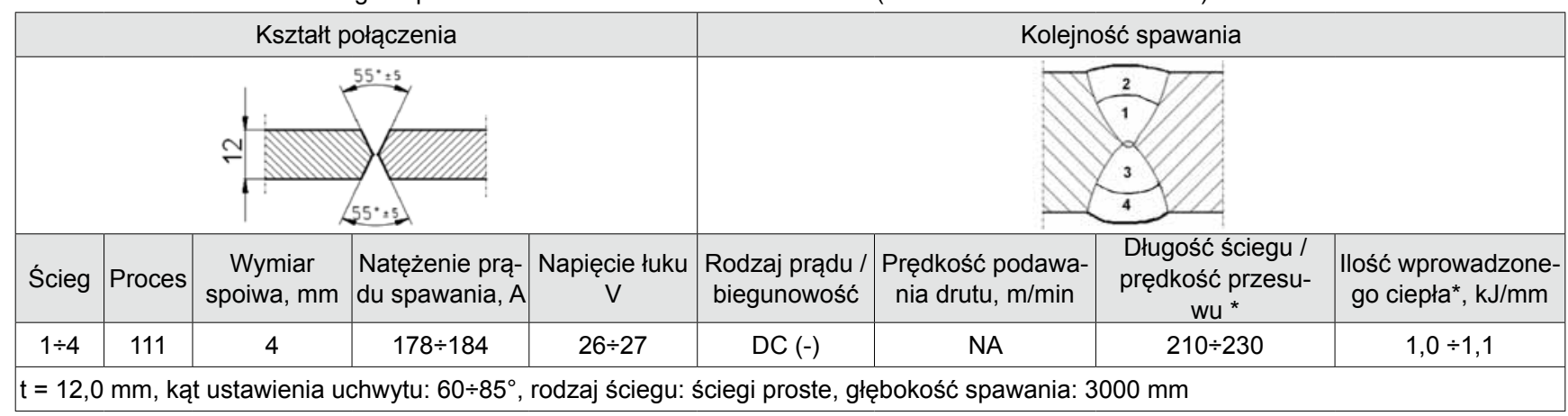




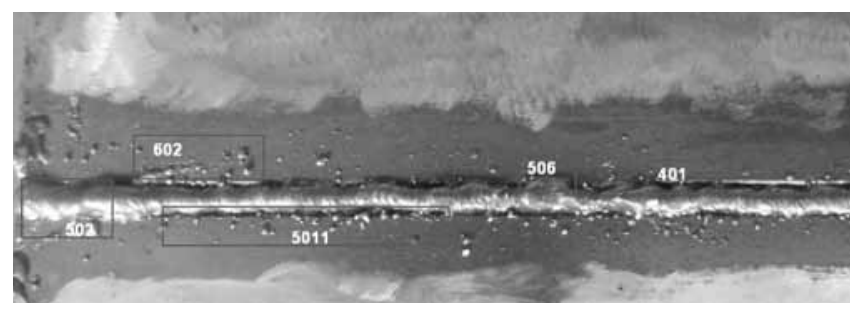

Rys. 3. Złącze próbne 12/111/PA z zaznaczonymi niezgodnościami spawalniczymi [11]

Fig. 3. Test specimen 12/111/PA with marked welding imperfections [11]

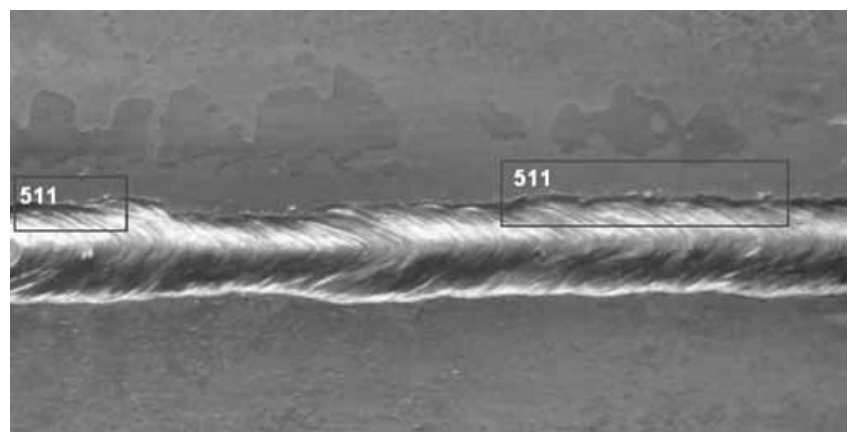

Rys. 4. Złącze próbne 10/111/PA z zaznaczonymi niezgodnościami spawalniczymi [11]

Fig. 4. Test specimen 10/111/PA with marked welding imperfections [11]

\section{Badania szczelności}

Badania szczelności wykonane metodą podciśnieniową miały na celu wskazanie ewentualnych nieszczelności w złączach spawanych. Badania wykonano przy użyciu testera szczelności Profos (rys. 5). Na rysunku 6 przedstawiono przykładowe złącze próbne podczas wykonywania badań.

Badania nie ujawniły nieszczelności złączy próbnych (brak pęcherzy gazowych podczas próby wokół spoin). Wszystkie próbki zostały ocenione pozytywnie.

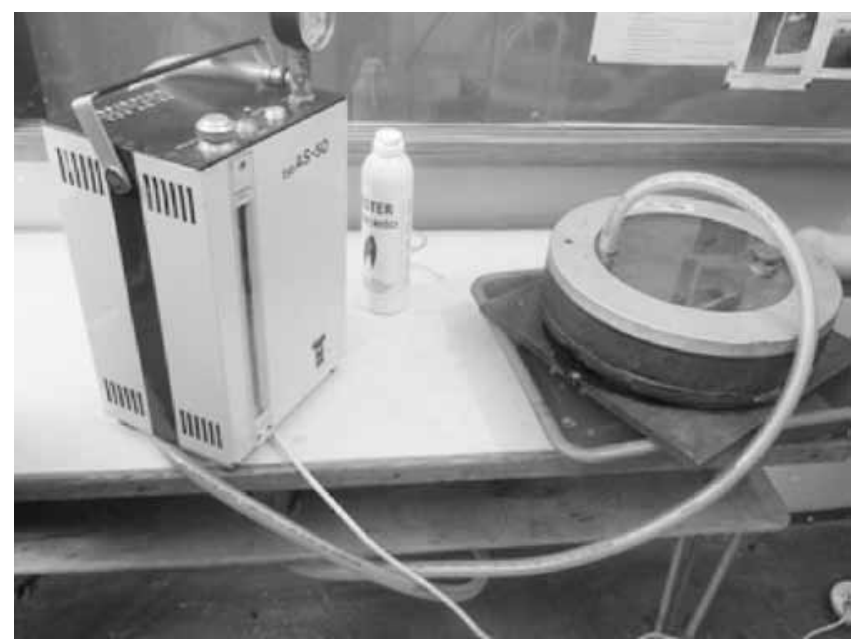

Rys. 5. Stanowisko do badania szczelności złączy spawanych przy zastosowaniu komory kołowej

Fig. 5. Stand for the investigation of leak tightness of welding joints with the use of the circular chamber

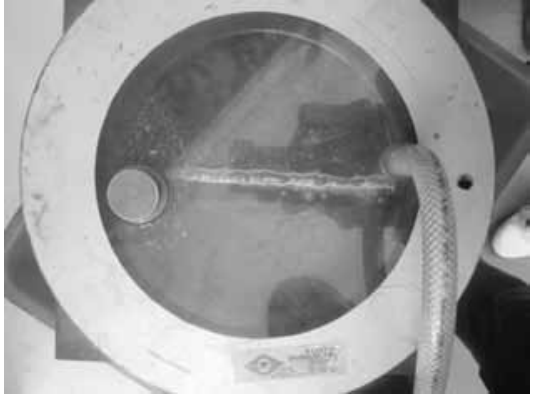

Rys. 6. Próbka 12/111/PA podczas wykonywania badania szczelności Fig. 6. View of the specimen 12/111/PA during executing the investigation of leak tightness

\section{Badania radiograficzne}

Złącza spawane poddano badaniom radiograficznym w celu ujawnienia niezgodności spawalniczych, których identyfikacja jest niemożliwa przy zastosowaniu metod do badań powierzchniowych. Badania radiograficzne (RT) przeprowadzono zgodnie z PN-EN ISO 1435. Na rysunkach 7 i 8 przedstawiono radiogramy złączy spawanych.

Badania radiograficzne wykazały występowanie niezgodności spawalniczych takich jak brak przetopu oraz żużle. Tego rodzaju nieciągłości są bardzo

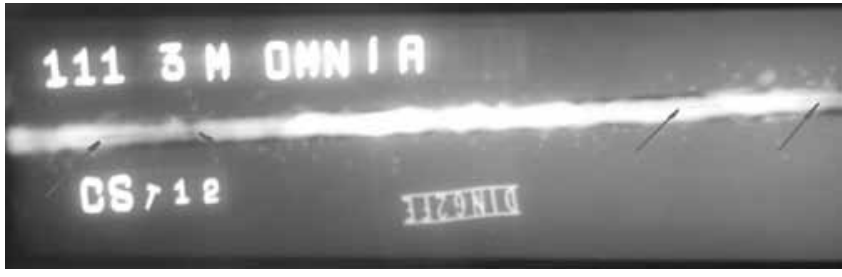

Rys. 7. Radiogram złącza spawanego 12/111/PA, widoczne niezgodności spawalnicze typu żużle lub brak przetopu na całej długości próbki (wskazane strzałkami) [11]

Fig. 7. The X-rays pattern of specimen 12/111/PA, visible welding imperfections: slags or lack of penetration on the whole length of the specimen (indicated by the arrows) [11]

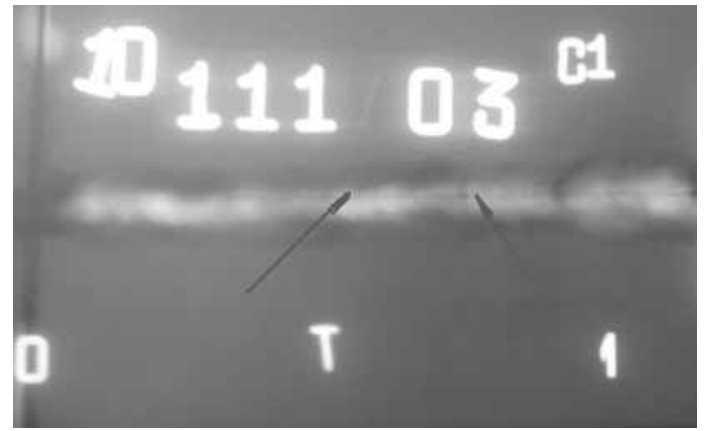

Rys. 8. Radiogram złącza spawanego 10/111/PA, widoczna niezgodność spawalnicza typu brak przetopu (wskazana strzałkami). Występuje na całej długości próbki [11]

Fig. 8. The X-rays pattern of specimen 10/111/PA, visible welding imperfections: lack of penetration on the whole length of the specimen (indicated by the arrows) [11] 
niebezpieczne dla nośności konstrukcji, w której mogą występować. Do najczęstszych przyczyn ich powstawania zalicza się: brak odpowiednich umiejętności nurka-spawacza, brak lub niedokładne czyszczenie po wykonaniu poszczególnych ściegów, nieodpowiednie parametry i technika spawania. W przypadku spawania elementów odpowiedzialnych złącza o takim nasileniu niezgodności są niedopuszczalne.

\section{Badania makroskopowe}

Próbki do badań makroskopowych zostały przygotowane zgodnie z normą PN-EN 1321. Wycięto je piłą taśmową, a następnie przygotowano do badań przez szlifowanie i polerowanie powierzchni zgładu oraz trawienie nitalem. Na rysunkach 9 i 10 przedstawiono zgłady metalograficzne wykonanych złączy próbnych.

Badania makroskopowe potwierdziły wyniki badań radiograficznych. Stwierdzono występowanie niezgodności spawalniczych typu brak przetopu oraz występowanie żużli. Przyczyną formowania się pierwszej nieciągłości w warunkach spawania pod wodą mogą być nieodpowiednie parametry spawania, ale w tym przypadku powstały one na skutek nieodpowiedniego ustawienia elektrody względem rowka spawalniczego (nieodpowiedni kąt pochylenia elektrody). Ta niezgodność pojawiła się w próbce 10/111/PA spawanej na głębokości $200 \mathrm{~mm}$.

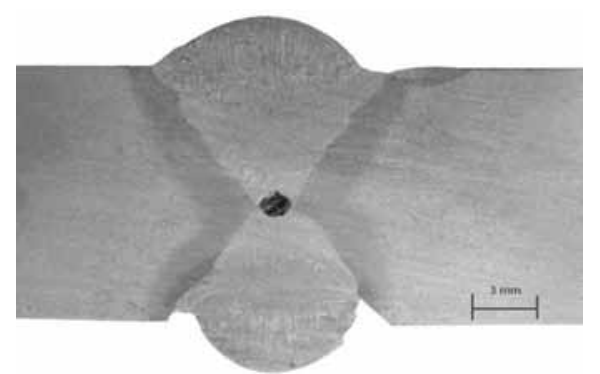

Rys. 9. Zgład metalograficzny próbki 12/111/PA, widoczna niezgodność spawalnicza typu żużel oraz brak wypełnienia rowka spawalniczego

Fig. 9. Cross section of specimen 12/111/PA, visible welding Imperfections: slag and incompletely filled groove

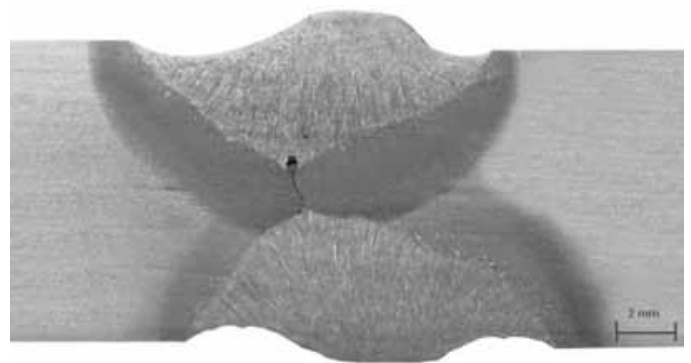

Rys. 10. Zgład metalograficzny próbki 10/111/PA, widoczna niezgodność spawalnicza typu żużel oraz brak przetopu

Fig. 10. Cross section of specimen 12/111/PA, visible welding Imperfections: slag and lack of penetration
Żużle występują w bardzo dużym nasileniu w złączu spawanym na głębokości 3000 mm. Przyczyną ich powstania było niedostateczne czyszczenie, związane w tym przypadku ze słabą widocznością w akwenie oraz zbyt małym kątem ukosowania rowka spawalniczego.

\section{Próba rozciągania}

W celu przeprowadzenia próby rozciągania ze złączy próbnych pobrano próbki o wymiarach zgodnych z zaleceniami normy PN-EN ISO 4136 [10]. Próbki do próby rozciągania poprzecznego przedstawiono na rysunku 11 . Uzyskane wyniki badań podano w tablicy IV.

Badania wykazały, że zrywanie próbek w każdym przypadku przebiega w materiale spoiny. Jest to skutkiem występowania niezgodności spawalniczych. Główne znaczenie mają tutaj: niepełne wypełnienie rowka spawalniczego, które determinuje powstawanie karbu, braki przetopu oraz żużle zmniejszające przekrój nośny w miejscu występowania niezgodności. Należy jednak zaznaczyć, że uzyskane wartości wytrzymałości na rozciąganie $\mathrm{R}_{\mathrm{m}}$ dla czterech próbek mieszczą się $\mathrm{w}$ granicach ustalonych normą dla stali S355J2G3 (480 $\leq R_{m} \leq$ 630 MPa). Tylko próbka 10/111/PA-0 charakteryzuje się niższą wartością $R_{m}$ w odniesieniu do wymagań normy (399,2 MPa). Niezgodności występujące na całej długości złączy próbnych pozwoliły na uzyskanie wartości $R_{m}$ mieszczących się $w$ ramach normy materiałowej. Elementy konstrukcji spawane pod wodą i poddane oddziaływaniu wyłącznie naprężeń rozciągających mogą być eksploatowane. Jednak w takim przypadku zaleca się stosowanie monitoringu stanu naprężeń, aby uniknąć ewentualnych awarii skutkujących np. skażeniem środowiska.

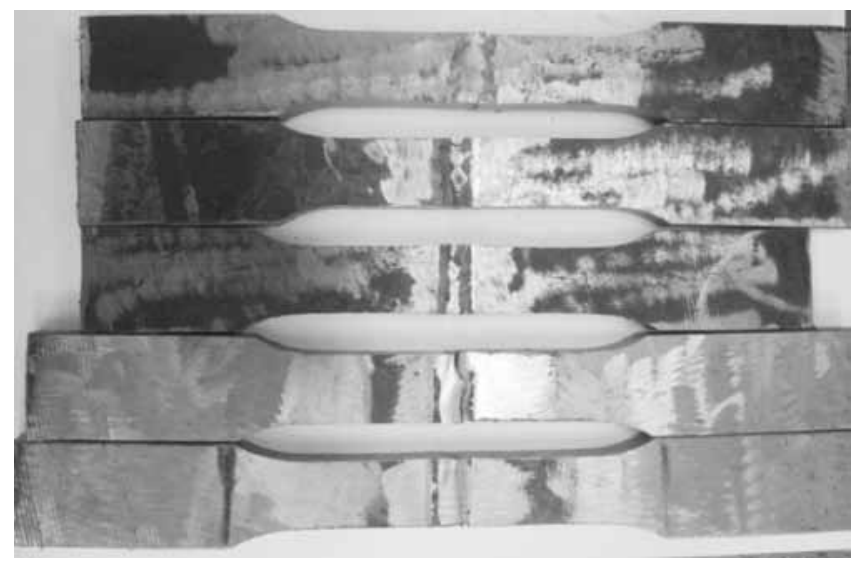

Rys. 11. Próbki przygotowane do próby rozciągania poprzecznego złączy spawanych pod wodą

Fig. 11. The view of underwater welded specimens prepared for the test of the transverse tension 
Tablica IV. Wyniki badań złączy próbnych 12/111/PA oraz 10/111/PA z próby rozciągania

Table IV. Results of tension test of welded specimens 12/111/PA and 10/111/PA

\begin{tabular}{|c|c|c|c|c|c|}
\hline Oznaczenie próbki & $\begin{array}{c}\text { Pole przekroju } \\
\text { poprzecznego } \mathrm{S}_{\circ}, \mathrm{mm}^{2}\end{array}$ & $\begin{array}{c}\text { Wartość siły } \\
\text { maksymalnej } \mathrm{F}_{\mathrm{m}}, \mathrm{N}\end{array}$ & $\begin{array}{c}\text { Wytrzymałość na } \\
\text { rozciąganie } \mathrm{R}_{\mathrm{m}}, \mathrm{MPa}\end{array}$ & Miejsce zerwania & Wynik badania \\
\hline 10/111/PA 0 & 250 & 99800 & 399,2 & negatywny \\
\hline 10/111/PA 8 & 250 & 122000 & 488,0 & negatywny \\
\hline 10/111/PA 9 & 250 & 148800 & 595,2 & spoina \\
\hline 12/111/PA 16 & 300 & 150000 & 500,0 & negatywny \\
\hline 12/111/PA 17 & 300 & 153000 & 543,0 & negatywny & spoina \\
\hline
\end{tabular}
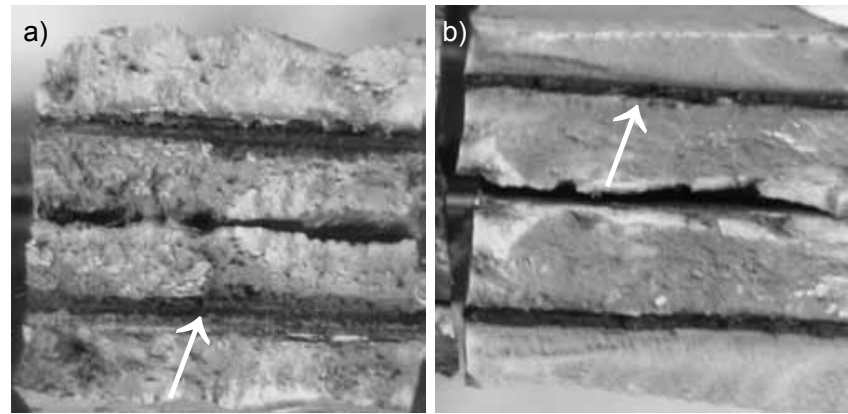

Rys. 12. Przełomy próbek po próbie rozciągania złączy spawanych: a) widoczny żużel na całej szerokości próbki; b) widoczny brak przetopu (ostre krawędzie)

Fig. 12. The view of the fractures of specimens after the tension test: a) visible slags on the whole width of the specimen; b) visible lacks of penetration (sharp edges)

Na rysunku 12 przedstawiono wybrane przełomy próbek po badaniach wytrzymałościowych.

Analizując przedstawione przełomy badanych próbek można zauważyć, że mają one charakter kruchy. Przyczyną takiego stanu powierzchni są zmiany strukturalne zachodzące podczas spawania pod wodą. Spowodowane jest to zwiększonymi prędkościami stygnięcia (krótszymi czasami stygnięcia w zakresie temperatury $800 \div 500^{\circ} \mathrm{C}-\mathrm{t}_{8 / 5}$ ) charakterystycznymi dla spawania mokrego elektrodami otulonymi. Dodatkowo przełomy ujawniły niezgodności wykryte podczas badań radiograficznych oraz makroskopowych.

\section{Próba zginania}

Próbę zginania wykonano zgodnie z PN-EN ISO 5173 [9]. Jest to badanie, które w prosty sposób weryfikuje jakość wykonanych złączy spawanych, która wynika z umiejętności nurków-spawaczy, zaprojektowanej technologii spawania (kształtu rowka spawalniczego, parametrów spawania itp.), właściwości materiałów podstawowych i dodatkowych do spawania, itp. Założono, że kryterium akceptacji będzie kąt gięcia nie mniejszy niż $180^{\circ}$, opierając się na wytycznych PN-EN ISO 15614-1. Wykonano badania $z$ rozciąganiem lica (FBB) oraz grani (RBB). W tablicy $V$ przedstawiono wyniki otrzymanych badań.

Na podstawie przeprowadzonej próby można zauważyć, że żadna z wykonanych próbek nie spełnia złożonego kryterium akceptacji (kąta gięcia $180^{\circ}$ ). Największy kat gięcia, jaki uzyskano, to $84^{\circ}$ dla próbki 3. Na takie wyniki wpłynęły występujące niezgodności spawalnicze, tzn. braki przetopu oraz żużle. Można założyć, że złącza z takimi rodza-jami niezgodności poddane naprężeniom gnącym doprowadzą do awarii bądź zniszczenia konstrukcji. Zidentyfikowane niezgodności muszą być usunięte, a połączenia wykonane ponownie oraz poddane badaniom nieniszczącym w celu weryfikacji jakości ich wykonania.

Tablica V. Wyniki badań złączy próbnych spawanych pod wodą po próbie zginania

Table V. Results of the bend tests of specimens welded underwater

\begin{tabular}{|c|c|c|c|c|c|c|}
\hline $\begin{array}{c}\text { Oznaczenie } \\
\text { próbki }\end{array}$ & $\begin{array}{c}\text { Rodzaj } \\
\text { próby }\end{array}$ & $\begin{array}{c}\text { Wymiary próbki } \\
\text { grubość } x \text { szerokość, } \mathrm{mm}\end{array}$ & $\begin{array}{c}\text { Średnica trzpienia } \\
\mathrm{d}, \mathrm{mm}\end{array}$ & $\begin{array}{c}\text { Odległość pomię- } \\
\text { dzy rolkami, mm }\end{array}$ & Kąt gięcia, ${ }^{\circ}$ & Wynik próby \\
\hline 4 & FBB & $10 \times 20$ & 25 & 50 & 42 & negatywny \\
\hline 5 & FBB & $10 \times 20$ & 25 & 50 & 44 & negatywny \\
\hline 3 & FBB & $10 \times 20$ & 36 & 60 & 84 & negatywny \\
\hline 7 & RBB & $10 \times 20$ & 36 & 60 & 73 & negatywny \\
\hline 9 & RBB & $10 \times 20$ & 36 & 60 & 47 & negatywny \\
\hline 11 & FBB & $12 \times 20$ & 25 & 55 & 56 & negatywny \\
\hline 12 & FBB & $12 \times 20$ & 25 & 55 & 66 & negatywny \\
\hline 13 & RBB & $12 \times 20$ & 25 & 55 & 59 & negatywny \\
\hline 14 & RBB & $12 \times 20$ & 25 & 55 & 44 & negatywny \\
\hline 15 & RBB & $12 \times 20$ & 25 & 55 & 54 & negatywny \\
\hline
\end{tabular}

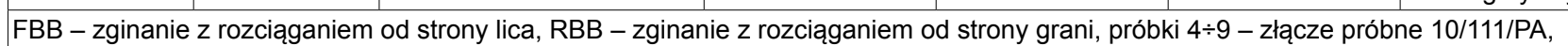
próbki $11 \div 15$ - złącze próbne 12/111/PA 


\section{Podsumowanie}

Wykonane badania nieniszczące oraz niszczące umożliwiły określenie rodzaju niezgodności spawalniczych i ich wpływu na szczelność oraz właściwości wytrzymałościowe złączy spawanych wykonanych pod wodą. Na podstawie badań wizualnych (VT), radiograficznych (RT) oraz makroskopowych stwierdzono występowanie niezgodności spawalniczych, które mogą wpływać na obniżenie właściwości mechanicznych. Zidentyfikowane niezgodności w złączach próbnych nie wpłynęły na ich szczelność. Każda z wykonanych próbek uzyskała wynik pozytywny $w$ próbie szczelności. Próba rozciągania złączy spawanych $w$ przypadku czterech próbek wykazała, że otrzymane wartości $R_{m}$ mieszczą się w ramach ustalonych normą przedmiotową $\left(480 \leq R_{m}\right.$ $\leq 630 \mathrm{MPa}$ ) (tabl. IV). Jedna z próbek nie osiągnęła wymaganego poziomu akceptacji dla $R_{m}(10 / 111 /$ PA 0; $\quad R_{m}=399,2 \mathrm{MPa}$ ). Niezgodności typu brak przetopu, żużle oraz niepełne wypełnienie rowka spawalniczego w tym przypadku nie spowodowały znacznego spadku wartości $R_{m}$ w stosunku do wymagań normy dla wartości maksymalnej. Wszystkie próbki zostały ocenione negatywnie ze względu na miejsce zerwania, które zlokalizowano w spoinie. Świadczyć to może w tym przypadku o zbyt krótkim czasie stygnięcia $t_{8 / 5}$, co doprowadziło do uformowania się kruchych struktur, o czym świadczą przełomy badanych próbek. Można jednak przypuszczać, że w przypadku występowania wyłącznie naprężeń rozciągających, konstrukcja z tego rodzaju niezgodnościami mogłaby pracować bezawaryjnie. Wtedy należałoby jednak zastosować monitorowanie stanu naprężeń $w$ danym węźle konstrukcyjnym. W przypadku naprężeń związanych ze zginaniem tego rodzaju niezgodności doprowadzą do utraty stateczności ustroju i jego zniszczenia. Otrzymane kąty gięcia z próby zginania są poniżej ustalonego kryterium, czyli $180^{\circ}$. Mieszczą się w przedziale $42 \div 84^{\circ}$. Są to wartości dużo poniżej dopuszczalnego kryterium. Ważnym aspektem w takim przypadku wydaje się możliwość wykonywania badań nieniszczących, np. badań ultradźwiękowych (UT) czy radiograficznych (RT), umożliwiających identyfikację różnego typu niezgodności. Pozwala to określić jakość wykonanych złączy w stopniu umożliwiającym ocenę stanu konstrukcji pod względem możliwości eksploatacyjnych (nośności). W celu wyeliminowania wykrytych niezgodności należy zmienić niektóre elementy technologiczne związane $z$ procesem spawania, np. kąt ukosowania rowka spawalniczego, średnicę elektrody, parametry spawania, liczbę ściegów oraz technikę czyszczenia poszczególnych warstw. W kolejnych badaniach należy uwzględnić wymienione elementy.

\section{Literatura}

[1] Christensen N.: The metallurgy of underwater welding. Proceedings of the International Conference „Underwater Welding”, Trondheim, Norway 1983.

[2] Lesiński K.J.: Metalurgiczne aspekty spawania pod wodą. Materiały konferencji naukowo-technicznej „Problemy cięcia i spawania pod wodą", ITMMiS, Gdańsk 1985.

[3] Hobler T.: Ruch ciepła i wymienniki. WNT, Warszawa 1979.

[4] Staniszewski B.: Wymiana ciepła. Podstawy teoretyczne. PWN, Warszawa 1963.

[5] Wiśniewski S.: Wymiana ciepła. PWN, Warszawa 1979.

[6] Rogalski G., Łabanowski J.: Certyfikowanie nurków-spawaczy przy spawaniu mokrym pod wodą w warunkach hiperbarycznych. Biuletyn Instytutu Spawalnictwa nr 1/2011.
[7] PN-EN ISO 17637: Spawalnictwo. Badania nieniszczące złączy spawanych. Badania wizualne.

[8] PN-EN ISO 1435: Badania nieniszczące złączy spawanych. Badania radiograficzne złączy spawanych.

[9] PN-EN ISO 5173: Badania niszczące spoin w materiałach metalowych. Badanie na zginanie.

[10]PN-EN ISO 4136: Badania niszczące złączy spawanych metali. Próba rozciągania próbek.

[11] Birosz B.: Badanie właściwości złączy spawanych pod wodą metodą mokrą. Praca dyplomowa stopnia magisterskiego realizowana pod kierunkiem dr. inż. Grzegorza Rogalskiego. Politechnika Gdańska, Gdańsk 2012.

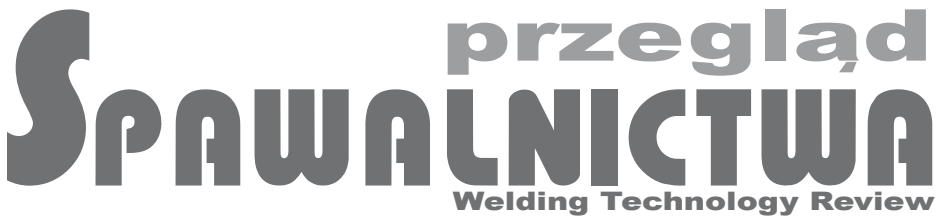 \\ www.pspaw.ps.pl}

